\title{
How do Disturbance-Generated Patterns INFLUENCE THE SPATIAL DYNAMICS OF ECOYSTEM PROCESSES?
}

\author{
MONICA G. TURNER \ DEPARTMENT OF ZOOLOGY \\ UNIVERSITY OF WISCONSIN $\downarrow$ MADISON \\ WILLIAM H. ROMME $\uparrow$ DEPARTMENT OF FOREST SCIENCES \\ COLORADO STATE UNIVERSITY $\uparrow$ FORT COLLINS \\ DANIEL B. TINKER $\uparrow$ DEPARTMENT OF BOTANY \\ UNIVERSITY OF WYOMING $\uparrow$ LARAMIE
}

\begin{abstract}
$\uparrow$ BACKGROUND
Our studies following the 1988 Yellowstone fires demonstrated that succession was surprisingly more variable in space and time than even current theory would have suggested, and that initial spatial patterns of disturbance may persist to produce longlasting changes in vegetation. Our focus now is on explaining the spatial and temporal patterns of succession and understanding how these patterns influence ecosystem function. The most interesting new questions revolve around the degree to which the spatial variation in postfire vegetation in particular, the six orders of magnitude variation in pine sapling density, ranging from 0 to greater than 500,000 saplings/ha controls the spatial variability in ecosystem processes across the landscape. In our current research, we are conducting studies in both Grand Teton and Yellowstone National Parks to answer four major questions:
\end{abstract}

1. Does the spatial heterogeneity of processes such as ANPP, nitrogen mineralization, and decomposition change with time since fire? How quickly do spatial patterns in processes develop following a large fire?
2. How does the spatial pattern of coarse woody debris vary across the post-1988 landscape, and what is the importance of this variation for ecosystem function? Are patterns of coarse woody debris abundance related to both prefire stand structure and postfire sapling density?

3. Do the enormous differences in postfire tree density produce differences in carbon and nitrogen availability across the landscape? Or, is nutrient availability governed largely by broad-scale (i.e., $10 \mathrm{~s}$ of $\mathrm{km}$ ) abiotic gradients (e.g., climate, substrate) and/or fine-scale (i.e., less than $10 \mathrm{~cm}$ ) heterogeneity in resources or the microbial community, such that nutrient variability is not sensitive to the spatial variation in plant community structure?

4. Does the disturbance-created mosaic leave a persistent functional legacy? What mechanisms in vegetation development may contribute to convergence (or divergence) in ecosystem structure and function across the landscape as succession proceeds? 


\section{FINDINGS AND STATUS}

\section{Studies in Grand Teton National Park}

Question 1: We initiated field studies during summer of 2001 in ten 0.25 -ha plots located within two fires that occurred during the summer of 2000: the Moran Fire, on the west side of Jackson Lake at the base of Mount Moran; and the Glade Fire, in the Rockefeller Parkway lands just south of the boundary of Yellowstone National Park. Within each of these fire sites, five study plots were established in areas of stand-replacing fire, three in crown fire and two in severe-surface burns. We are studying the development of postfire vegetation, sampling the number and species of tree seedlings and the percent cover (by species) of all other vegetation; the availability of inorganic nitrogen using ion-exchange resin that is incubated in the field for a year in small soil cores; the concentration of nitrogen in the vegetation of different species in the burned plots and adjacent unburned locations; and the presence and abundance of soil microbial functional groups. We are using a cyclic sampling design derived from spatial statistics and designed to detect the spatial scale of variation in nutrient availability, and we are remeasuring these sites through successional time. We will estimate herbaceous aboveground net primary production and leaf area in these recently burned stands because we expect the rate of recovery of these processes to influence nitrogen and carbon availability. Changes in spatial patterns and in mean rates of all response variables are being tracked through time by repeating the measurements through 2004.

From the 2001 and 2002 vegetation data, we found that lodgepole pine seedlings were more abundant and species richness was greater in surface fires than in crown fires, similar to our observations following the 1988 fires. However, tree seedlings were generally scarce at the Moran site, which was spruce-dominated forest prior to the 2000 fires. Analyses of the 2002 foliar N samples revealed significant variation among species, with the highest values observed in Lupinus argenteus and the lowest values in Calamagrostis rubescens.

Under direction of two postdoctoral associates (Drs. Erica Smithwick and Kristine Metzger), stable isotope uptake studies to determine whether young lodgpole pine seedlings were taking up inorganic nitrogen and/or organic nitrogen were initiated in the Glade Fire during summer 2002. The sampling consisted of injections of (1) ${ }^{15} \mathrm{NH}_{4},(2){ }^{13} \mathrm{C}$ ${ }^{15} \mathrm{~N}$ glycine, and (3) distilled water, as control, into subplots that included a lodgepole pine seedling. Injections were administered on a grid placed over the vegetation in the subplot. Injection volumes were administered in $2 \mathrm{ml}$ amounts at a maximum concentration of $0.24 \mathrm{~g}^{15} \mathrm{~N} \mathrm{~m}^{-2}$ for both labeled solutions. Total injection area did not exceed $7 \mathrm{~m}^{2}$ for the entire experiment. Sampling of pine seedlings and soils was done 2 hours, 24 hours, and 7 days after injections to follow the fate of the nitrogen as it is cycled by the microbial community and potentially used by plants.

\section{Studies in Yellowstone National Park}

During the summer of 2002, our field studies focused on questions associated with the ecological role of postfire coarse woody debris and with convergence or divergence in ecosystem structure and function through time.

Question 2. We initiated studies in 2002 of the influence of postfire coarse woody debris on soil nutrient dynamics and decomposition in three locations burned in the 1988 fires under the leadership of co-PI Dr. Daniel B. Tinker and postdoctoral associate Dr. Kristine Metzger. At each site, we collected soil samples from positions located under trees that have fallen since the 1988 fires, under wood that was down prior to the 1988 fires, under lodgepole pine saplings, and out in the open. The effect of coarse woody debris on nitrogen availability was measured using 1-yr incubations of ion exchange resin placed in soil cores at each site during summer 2002. In addition, we are characterizing the microbial community composition of the soil, enzyme activity levels, and gross nitrogen mineralization in the laboratory.

Decomposition studies were initiated in 2002 by placing litterbags containing herbaceous litter or conifer litter in each of the positions described above. These decomposition studies are continuing for two years, with half of the bags to be retrieved in 2003 and the remainder in 2004. This study will form the basis of a MS thesis for Alysa Remsburg, student at University of Wisconsin.

To explain and predict variation in the rates of treefall and abundance of postfire coarse woody debris, extensive sampling was begun during summer 2002 to quantify downed wood throughout the area burned by the 1988 fires. This sampling was the first of two field seasons that will result in a MS thesis for Heather Lyons, student at Colorado State University. Results of the 2002 sampling revealed that while most (86\%) trees killed in the 1988 fires had fallen to 
the ground, there was very wide spatial variation in treefall among stands (ranging from 0 to $98 \%$ of trees down in 131 stands). Trees killed in 1988 were more likely to have fallen by 2002 at lower elevations.

Question 3. Not addressed during the 2002 field season.

Question 4. Soils and vegetation were analyzed in 20 lodgepole pine (Pinus contorta) forest stands, varying in age from 50 to 350 years, that had initiated following stand-replacing fire. Our goal of this study, lead by postdoctoral associate Dr. Erica A. H. Smithwick, was to determine how nitrogen availability $\left(\mathrm{NH}_{4}{ }^{+}-\mathrm{N}\right)$ and microbial community composition varied with stand age-class and to determine whether differences could be explained by canopy, soil, or understory characteristics. Gross $\mathrm{NH}_{4}{ }^{+}$mineralization was measured using laboratory isotopic pool dilution and microbial community composition was evaluated using microbial membrane lipids. The microbial community composition of stands in the 300-350 age class was distinct from stands in younger age classes. Microbial community composition among sites varied with $\mathrm{pH}, \%$ organic matter, and phosphorus. Gross $\mathrm{NH}_{4}{ }^{+}$mineralization rates averaged $1.45 \pm 0.07$ $\mathrm{mg} \mathrm{NH}_{4}{ }^{+} \mathrm{kg} \mathrm{soil}^{-1} \mathrm{~d}^{-1}$ while consumption averaged $1.37 \pm 0.20 \mathrm{mg} \mathrm{NH}_{4}{ }^{+} \mathrm{kg} \mathrm{soil}^{-1} \mathrm{~d}^{-1}$, resulting in low net $\mathrm{NH}_{4}{ }^{+}$mineralization rates $\left(0.08 \pm 0.18 \mathrm{mg} \mathrm{NH}_{4}{ }^{+} \mathrm{kg}\right.$ soil $^{-1} \mathrm{~d}^{-1}$ ), but rates were not significantly different with stand age-class at $\mathrm{p}<0.05$. At $\mathrm{p}<0.10$, net $\mathrm{NH}_{4}{ }^{+}$ mineralization was significantly higher in the 300350 age class compared to the 125-175 age class. None of the measured variables significantly explained $\mathrm{NH}_{4}{ }^{+}$consumption and net mineralization patterns. However, gross $\mathrm{NH}_{4}^{+}$mineralization rates were best explained by information on microbial community structure (i.e., lipids). Variation among stands within a given age-class was high, indicating that predictions of $\mathrm{N}$ cycling across landscapes must account for substantial heterogeneity among mature stands.

\section{ACKNOWLEDGEMENT}

This research is supported by a grant from the Andrew W. Mellon Foundation. 